\title{
PENGARUH UMUR, GENDER, DAN PENDIDIKAN TERHADAP PERILAKU RISIKO AUDITOR DALAM KONTEKS AUDIT ATAS LAPORAN KEUANGAN
}

\author{
Taufiequr R. Wirosari., SE., Ak. \\ Dr. Zaenal Fanani., SE., MSA., Ak. \\ Fakultas Ekonomi dan Bisnis, Universitas Airlangga, Surabaya \\ Email : taufiequr.rakhman@gmail.com
}

\begin{abstract}
This research aims to examines and proves the influence of auditor's risk behavior generated by age, gender, and education. This is important because risk is the main focus on Professional Standard on Auditing (PSA) as auditor guidance to audit of financial statement, so it is important to examine that auditor perception and propensity to face that risk.

This study is a quantitative approach, which respondents are auditors involved in the audit of financial statements in Indonesian. The data was collected using a questionnaire Ionescu \& Turlea (2011). This research using age (X1), gender (X2), and education (X3) as independent variable and auditor's risk behavior (Y) as dependent variable. Hypothesis testing was performed using multiple linear regression with a 5\% significance level. The result show age has a positive and significant influence on auditor's risk behavior, in a financial audit context, while gender and education has not significant influence on auditor's risk behavior.
\end{abstract}

Keywords: Risk Averse, Age, Gender, Education, Auditor's Risk Behavior.

\section{PENDAHULUAN}

Literatur mengenai umur pada umumnya sering dikaitkan dengan perilaku menghindar risiko, dimana umur berpengaruh signifikan terhadap pola pikir dan respon individu terhadap risiko yang dihadapinya, semakin berumur individu maka akan cenderung bereaksi terhadap risiko yang teridentifikasi (Riley \& Chow, 1992; Wang \& Hanna 1997; Dror et al., 1998; Bellante \& Green, 2004, Chang et al., 2004; Gardner \& Steinberg, 2005; Grable et al., 2009; Chauffman et al., 2010; Ionescu \& Turlea, 2011; Yao et al., 2011; Amaefula et al., 2012; Rolison et al., 2012; Duasa \& Yusof, 2013), akan tetapi terdapat ketidakkonsistenan hasil temuan mengenai pengaruh umur dan perilaku menghindar risiko dimana banyak penelitian yang membuktikan bahwa perilaku menghindar risiko akan meningkat seiring dengan bertambahnya umur (Riley \& Chow, 1992; Bellante \& Green, 2004; Chang et al., 2004; Gardner \& Steinberg, 2005; Grable et al., 2009; Chauffman et al., 2010; Ionescu \& Turlea, 2011; Yao et al., 2011; Rolison et al., 2012; Duasa \& Yusof, 2013). Namun dilain pihak juga tidak sedikit penelitian yang menyatakan bahwa perilaku menghindar risiko akan menurun seiring bertambahnya umur, dengan kata lain, semakin berumur seseorang maka semakin menyukai risiko (Wang \& Hanna, 1997; Lin, 2009; Amaefula et al. 2012). 
Permasalahan yang sama tentunya akan muncul pada diri seorang auditor selama proses audit atas laporan keuangan berlangsung. Semakin berumur auditor, maka auditor tersebut akan lebih konservatif dalam memperoleh bukti untuk menekan risiko ke tingkat yang paling rendah, dengan kata lain prosedur dan pengumpulan sampel lebih banyak untuk membuktikan kebenaran dari laporan keuangan yang disusun oleh manajemen perusahaan, sehingga persentase keyakinan atas opini yang dijaminnya semakin besar. Hal ini tentunya menambah biaya dan waktu pelaksanaan audit di lapangan, begitu juga sebaliknya.

Penelitian ini terinspirasi dari penelitian yang dilakukan oleh Ionescu \& Turlea (2011) di Romania mengenai pengaruh umur terhadap perilaku risiko auditor dalam konteks audit atas laporan keuangan dengan maksud membuat penelitian yang serupa dengan kondisi di Indonesia, sekaligus mengembangkan penelitian tersebut, melalui penambahan variabel tambahan yaitu gender dan pendidikan sebagai variabel independen dari perilaku risiko auditor.

Motivasi penelitian ini adalah sebagai berikut: pertama, umur sering dikaitkan secara langsung mempengaruhi perilaku menghindar risiko, pendapat umum seputar perilaku menghindar risiko selama ini ialah semakin berumur seseorang maka akan cenderung untuk menghindari risiko, dan sebaliknya (Riley \& Chow, 1992; Wang \& Hanna 1997; Dror et al., 1998; Bellante \& Green, 2004, Chang et al., 2004; Gardner \& Steinberg, 2005; Grable et al., 2009; Chauffman et al., 2010; Ionescu \& Turlea, 2011; Yao et al., 2011; Amaefula et al., 2012; Rolison et al., 2012; Duasa \& Yusof, 2013). Selain itu, variabel gender tidak kalah menariknya, gender tidak jarang digunakan sebagai variabel yang mempengaruhi perilaku risiko, perempuan sering disimpulkan lebih berperilaku menghindar risiko dibandingkan laki-laki, hal ini didukung dengan penelitian empiris dari (Riley \& Chow, 1992; Barber \& Odean, 2001; Faff et al., 2008; Duasa \& Yusof, 2013; Jayathilake, 2013). Selanjutnya, pendidikan juga sering dikaitkan dengan cara seseorang menghadapi risiko, semakin berpendidikan seseorang, maka akan semakin berperilaku menyukai risiko dan berlaku sebaliknya (Riley \& Chow, 1992; Chang et al., 2004; Lin, 2009; Amaefula et al. 2012; Duasa
\& Yusof, 2013). Penelitian ini berusaha untuk lebih lanjut menguji pengaruh umur, gender, dan pendidikan terhadap perilaku menghindar risiko yang terkait dengan auditor dalam konteks audit atas laporan keuangan.

Kedua, berbagai penelitian sebelumnya menunjukkan hasil yang tidak konsisten pada variabel umur dimana Riley \& Chow (1992), Bellate (2004), Chang et al. (2004), Gardner \& Steinberg (2005), Grable (2009), Chauffman et al. (2010), Yao et al. (2011), Rolison et al. (2012), dan Duasa \& Yusof (2013) menyatakan bahwa semakin bertambahnya umur, perilaku menghindar risiko semakin meningkat. Hal ini bertentangan dengan penelitian yang dilakukan oleh Wang \& Hanna (1997), Lin (2009), dan Amaefula et al. (2012) yang menyatakan sebaliknya, semakin bertambahnya umur, perilaku menghindar risiko akan semakin menurun, dengan kata lain, semakin bertambahnya umur individu akan lebih menyukai risiko. Bahkan Dror et al. (1998), Faff et al. (2008), dan Jayathilake (2013) tidak menemukan adanya pengaruh signifikan antara umur dan perilaku risiko. Sedangkan pada variabel gender Barber \& Odean (2001), Faff et al. (2008), dan Jayathilake (2013) yang menyatakan perempuan lebih berperilaku menghindar risiko dibandingkan dengan laki-laki. Hal ini bertentangan dengan penelitian yang dilakukan oleh Grable et al. (2009) dan Wendy (2010) yang menyatakan tidak ada perbedaan perilaku risiko antara laki-laki dan perempuan. Selanjutnya pada variabel pendidikan menurut Riley \& Chow (1992), Chang et al. (2004) dan Duasa \& Yusof (2013) semakin tinggi pendidikan seorang individu akan semakin menurunkan perilaku menghindar risikonya. Hal ini bertentangan dengan penelitian yang dilakukan oleh Lin (2009), dan Amaefula et al. (2012) yang menyatakan sebaliknya, semakin berpendidikan individu, maka akan semakin meningkatkan perilaku menghindar risiko. Bahkan Grable et al. (2009) dan Jayathilake (2013) justru menyatakan tidak ada bukti signifikan yang menunjukkan pengaruh pendidikan dengan perilaku risiko yang ada.

Di Indonesia jenjang pendidikan formal di bidang akuntansi umumnya dilewati melalui jenjang kesarjanaan (S1), jenjang pendidikan profesional (PPA), jenjang pendidikan magister (S2), hingga jenjang 
pendidikan doktoral (S3), adapun pendidikan profesional yang diambil setelah seseorang mengenyam pendidikan magister dan doktoral merupakan penyesuaian semata.

Pentingnya pendidikan formal tentunya membantu auditor dalam membentuk pola pikir dasar, memetakan risiko terkait proses audit, serta merumuskan program audit sesuai dengan ketentuan yang disyaratkan oleh standar audit. Dalam hal ini tentunya tidak sama penilaian dan respon auditor yang hanya mengenyam pendidikan sarjana dengan auditor yang mengenyam pendidikan profesional dan seterusnya mengenai risiko yang dihadapi selama proses audit.

Ketiga, penelitian ini berusaha memperbaiki pengukuran sesuai dengan yang disarankan oleh Ionescu \& Turlea (2011) untuk menambahkan poin penilaian pada skala linkert dalam pengukuran kuesioner yang akan disebar dengan tujuan untuk memperoleh hasil yang lebih halus dengan tetap tidak mempergunakan poin netral pada skala linkert untuk menghindari bias atas pilihan yang ada.

Ketidakkonsistenan hasil penelitian yang ada diatas, membutuhkan adanya generalisasi terhadap fenomena yang ada, oleh karenanya penelitian ini berusaha mengintegrasikan dan mengajukan bahwa umur, gender, dan pendidikan merupakan faktor transeden yang mempengaruhi perilaku menghindar risiko (risk aversion behavior) auditor dalam konteks audit atas laporan keuangan. Berdasarkan latar belakang penelitian yang telah dibahas sebelumnya, maka rumusan masalah pada penelitian ini sebagai berikut :

1. Apakah umur berpengaruh positif terhadap perilaku risiko auditor dalam konteks audit atas laporan keuangan?

2. Apakah gender berpengaruh terhadap perilaku risiko auditor dalam konteks audit atas laporan keuangan?

3. Apakah pendidikan berpengaruh negatif terhadap perilaku risiko auditor dalam konteks audit atas laporan keuangan

\section{TINJAUAN PUSTAKA \\ Teori Disonansi Kognitif}

Menurut Festinger (1962) menyatakan bahwa teori disonansi kognitif terjadi jika seseorang mengetahui beberapa hal yang secara psikologi tidak konsisten dengan kondisi umumnya, dalam beberapa kondisi, mencoba untuk membuatnya konsisten. Dua informasi yang secara psikologi tidak cocok dikatakan sebagai ketidakkonsistenan. Beberapa bagian dari informasi tersebut dapat berkaitan dengan perilaku, perasaan-perasaan, opini-opini, sesuatu yang berkenaan dengan lingkungan dan lain sebagainya. Secara sederhana, kata "kognitif" menguji teori yang berkaitan dengan hubungan antar informasi.

Serangkaian informasi yang dialami oleh auditor membuat auditor tersebut akan berusaha mencapai keselarasan antara sikap dan perilaku yang seharusnya. Dalam konteks penelitian ini, teori ini membantu menjelaskan perilaku risiko auditor saat bertambahnya umur, semakin berumur auditor akan cenderung untuk semakin konservatif terhadap bukti yang menyebabkan pembengkakan terhadap waktu dan biaya, sedangkan dilain pihak adanya tekanan untuk melakukan audit dengan lebih efisien memaksa auditor untuk cenderung mengambil risiko. Semakin berpendidikan auditor akan semakin mengetahui dampak yang akan terjadi jika mengambil risiko sehingga menyebabkan menghindari risiko, sedangkan dilain pihak auditor juga memiliki materialitas tersendiri untuk menanggung risiko auditnya. Hal yang serupa juga terjadi antara auditor laki-laki dan auditor perempuan. Teori disonansi kognitif ini membantu menjelaskan pengaruh umur, gender, dan pendidikan terhadap perilaku risiko auditor, dimana sifat psikologi manusia pada dasarnya mencari kenyamanan dalam segala situasi membuat teori ini menjadi dasar mengapa auditor yang lebih berumur dan berumur dibawahnya, laki-laki dan perempuan, lebih berpendidikan dan pendidikan dibawahnya memiliki perbedaan dalam menghadapi risiko.

\section{Perilaku Risiko Auditor}

Menurut Sitkin \& Pablo (1992) perilaku risiko adalah keputusan risiko terkait yang muncul dari keputusan yang diambil, keputusan berisiko yang dimaksud termasuk ketidakpastian yang lebih atas keluaran (outcomes) yang dihasilkan, penentuan tujuan yang sulit untuk dicapai, termasuk konsekuensi ekstrim yang harus diterima sebagai dampak dari keputusan yang diambil.

Sedangkan menurut SA 200 Paragraf 13 (d) istilah auditor digunakan untuk menyebut 
dua subyek yaitu seseorang yang melaksanakan audit, dalam hal ini rekan perikatan atau anggota team perikatan atau Kantor Akuntan Publik itu sendiri. Jika yang dimaksud oleh SA menyatakan bahwa suatu ketentuan atau tanggung jawab harus dipenuhi oleh rekan perikatan, maka tidak lagi menggunakan istilah auditor, namun istilah yang lebih tepat digunakan langsung mengarah kepada rekan perikatan.

Berdasarkan terminologi diatas mengenai perilaku risiko dan auditor, maka dapat disimpulkan bahwa perilaku risiko auditor adalah keputusan risiko terkait yang muncul dari keputusan yang diambil orang-orang yang melaksanakan audit, biasanya rekan perikatan atau anggota team perikatan, keputusan berisiko yang dimaksud termasuk ketidakpastian yang lebih atas keluaran (outcomes) yang dihasilkan, penentuan tujuan yang sulit untuk dicapai, termasuk konsekuensi ekstrim yang harus diterima sebagai dampak dari keputusan.

\section{KERANGKA KONSEPTUAL}

Penelitian ini berangkat dari penelitian yang dilakukan oleh Ionescu \& Turlea (2011) yang menguji pengaruh umur terhadap perilaku risiko auditor yang terlibat perikatan audit atas laporan keuangan. Pertimbangan penggunaan umur dikarenakan umur merupakan satu dari sekian banyak penentu perilaku risiko pengambil keputusan. Penelitian yang dilakukan oleh Bellante \& Green (2004), Chang et al. (2004), Grable et al. (2009), Chauffman et al. (2010), Ionescu \& Turlea (2011), Yao et al. (2011), Rolison et al. (2012), Duasa \& Yusof (2013) menunjukkan bahwa perilaku menghindar risiko akan meningkat seiring dengan bertambahnya umur. Berdasarkan simpulan dari penelitian sebelumnya mengenai peningkatan perilaku menghindar risiko seiring dengan bertambahnya umur, seharusnya juga berlaku pada auditor. Dengan semakin bertambahnya umur auditor yang terlibat dalam perikatan audit atas laporan keuangan, maka akan semakin konservatif untuk memilih risiko yang lebih rendah (risk aversion behavior).

Dalam mempertimbangkan faktor yang mempengaruhi perilaku menghindar risiko, perempuan dianggap lebih berperilaku menghindar risiko dibandingkan dengan lakilaki, sesuai dengan hasil penelitian yang dilakukan oleh Riley \& Chow (1992), Barber \& Odean (2001), Duasa \& Yusof (2013),
Jayathilake (2013) yang menunjukkan hasil laki-laki dan perempuan mempunyai perilaku yang berbeda dalam menghadapi risiko. Berdasarkan penelitian terdahulu, perempuan dianggap lebih berperilaku menghindar risiko dibandingkan dengan laki-laki. Atas kenyataan tersebut, maka tidak menutup kemungkinan hal yang sama bahwa auditor perempuan memiliki perilaku risiko yang lebih tinggi dibandingkan dengan auditor laki-laki.

Karakteristik demografis lainnya yang dapat mempengaruhi perilaku risiko auditor ialah pendidikan. Pendidikan yang dimaksudkan pada penelitian ini adalah pendidikan formal. Pendidikan formal adalah proses memperoleh pengetahuan pada institusi yang pasti seperti sekolah tinggi, institut dan universitas. Sesuai dengan penelitian yang dilakukan oleh Riley \& Chow (1992), Chang et al. (2004), Lin (2009), Amaefula et al (2012), Duasa \& Yusof (2013) yang secara umum menunjukkan bahwa latar belakang pendidikan dapat mempengaruhi karakteristik perilaku risiko dari individu oleh karenanya semakin tinggi pendidikan dari auditor maka akan cenderung memilih perikatan audit atas laporan keuangan dengan risiko yang lebih tinggi, dengan kata lain semakin tinggi pendidikan auditor, maka perilaku menghindar risiko akan semakin menurun.

\section{Penelitian Sebelumnya dan Pengembangan Hipotesis \\ Pengaruh Umur Terhadap Perilaku Risiko Auditor}

Umur merupakan salah satu faktor utama yang dapat mempengaruhi perilaku risiko auditor. Hal ini terjadi karena makin lama auditor akan terbiasa dalam memahami kondisi yang akan datang (intuisi) atas risiko perikatan audit atas laporan keuangan yang akan ditanganinya. Disamping itu, umur juga dapat menunjukkan kematangan profesional dibidangnya. Dengan demikian umur berpengaruh terhadap peningkatan perilaku menghindar risiko (risk aversion behavior). Pada kenyataannya, auditor sering mengalami konflik pada saat penugasan audit. Menurut Festinger (1962) apabila terjadi disonansi, maka seseorang akan berusaha untuk mengurangi disonansi tersebut untuk mencapai konsonansi, hal ini dicapai dengan merubah sikap dan perilakunya. Auditor akan mengalami disonansi kognitif apabila ia telah terbentuk dari latar belakang lingkungan yang 
tidak sedemikian mengerti mengenai risiko akan berperilaku menyukai risiko, sehingga perilaku risiko auditor semakin rendah, perilaku tersebut akan berubah seiring dengan bertambahnya umur auditor, setelah semakin banyak mengetahui risiko yang dihadapinya, maka auditor tersebut akan menjadi semakin menghindari risiko.

Riley \& Chow (1992) menyatakan terdapat pengaruh signifikan negatif antara umur dan persentese kepemilikan aset yang berisiko, semakin berumur seseorang akan semakin berperilaku menghindar risiko (risk aversion behavior). Wang \& Hanna (1997) menyatakan sebaliknya, bahwa perilaku menghindar risiko akan menurun seiring dengan bertambahnya umur. Dilain pihak, Dror et al. (1998) berusaha untuk mengonfirmasi perbedaan tersebut dan melakukan pengujian kembali mengenai perbedaan perilaku pengambil keputusan antara yang berumur dan yang lebih muda, hasil penelitian tersebut menyimpulkan bahwa pada tingkatan tertentu dimana risiko ditingkatkan, maka antara kelompok yang lebih berumur dan yang lebih muda tidak menunjukkan perbedaan, kedua kelompok tersebut menunjukkan hasil peningkatan perilaku menghindar risiko yang sama.

Bellante \& Green (2004) menyimpulkan bahwa kelompok yang lebih tua akan semakin menghindari risiko ketika beranjak lebih tua. Chang et al. (2004) menyatakan bahwa pada umur diatas 65 tahun, ibu rumah tangga akan lebih berperilaku menghindar risiko. Gardner \& Steinberg (2005) menyatakan bahwa perilaku pengambil risiko pada pengambil keputusan akan cenderung menurun seiring dengan peningkatan umur.

Grable et al. (2009) menemukan bahwa individu yang berumur lebih akan mengesampingkan adanya risiko/ lebih menghindar terhadap risiko yang ada. Lin (2009) pada umur 40 tahun, ibu rumah tangga akan lebih menyukai risiko dibandingkan dengan umur sebelumnya. Chauffman et al. (2010) dengan meningkatnya umur, maka perilaku menghindar risiko (avoidance risk behavior) akan semakin meningkat. Yao et al. (2011) menyimpulkan bahwa umur memiliki dampak negatif terhadap keinginan untuk memiliki aset keuangan yang berisiko. Namun, Amaefula et al. (2012) berpendapat sebaliknya, bahwa umur memiliki pengaruh signifikan positif terhadap perilaku risiko (risk attitude).
Rolison et al. (2012) menemukan bahwa individu yang lebih tua lebih berperilaku menghindari risiko dibandingkan dengan yang berumur lebih muda. Duasa \& Yusof (2013) menyatakan bahwa perilaku menghindar risiko lebih kecil komposisinya pada individu yang berumur dibawah investor yang lebih berumur.

Faktor terpenting yang dapat mempengaruhi perilaku risiko auditor dalam menghadapi risiko adalah umur dari auditor itu sendiri, semakin berumur auditor akan cenderung untuk berperilaku menghindari risiko. Berdasarkan hasil penelitian dari Riley \& Chow (1992), Bellante \& Green (2004), Chang et al. (2004), Gardner \& Steinberg (2005), Grable et al. (2009), Chauffman et al. (2010) Ionescu \& Turlea (2011), Yao et al. (2011), Rolison et al. (2012) yang menyatakan bahwa semakin berumur seseorang, perilaku menghindar risiko akan semakin meningkat, maka dikembangkan rumuskan hipotesis sebagai berikut :

H1 : Semakin bertambah umur auditor maka perilaku risiko auditor dalam konteks audit atas laporan keuangan akan semakin meningkat.

\section{Pengaruh Gender Terhadap Perilaku Risiko Auditor}

Kepercayaan umum bahwa laki-laki seharusnya mengambil risiko yang lebih besar dibandingkan perempuan, dimana perempuan pada umumnya lebih berperilaku menghindar risiko dibandingkan dengan laki-laki. Teori disonansi kognitif gender menyatakan bahwa perbedaan sifat dan karakter bawaan dari lakilaki dan perempuan dapat mempengaruhi perilaku dan pola pikir yang berbeda. Hal ini menjadi pertimbangan faktor terpenting selanjutnya yang dapat mempengaruhi perilaku risiko auditor. Riley \& Chow (1992) menemukan bahwa perilaku menghindar risiko akan lebih rendah pada laki-laki jika dibandingkan dengan perempuan. Lebih lanjut laki-laki lebih mempunyai tekanan yang lebih "thrill seeker" atau pencari sensasi, sehingga secara konsekuensi laki-laki akan cenderung untuk lebih menyukai risiko, yang akan berbanding terbalik dengan perempuan, dimana pada konteks ini perempuan menjadi lebih berperilaku menghindar risiko dibandingkan dengan laki-laki.

Faff et al. (2008) melakukan pengujian terhadap pengaruh financial risk tolerance (FRT) terhadap perilaku menghindar risiko 
dengan menggunakan survey online FRT metric menyimpulkan bahwa pada umumnya perempuan lebih berperilaku menghindar risiko dibandingkan dengan laki-laki, yang ditunjukkan dari tendensi untuk lebih banyak pilihan menyimpan dari pada bertaruh pada risiko. Hal ini didukung dengan penelitian Jayathilake (2013) atas perilaku risiko pengusaha laki-laki dan perempuan di Sri Lanka yang membuktikan bahwa pada dasarnya perempuan lebih berperilaku menghindar risiko dibandingkan dengan pengusaha laki-laki. Berdasarkan hasil penelitian dari Riley \& Chow (1992), Faff et al. (2008), Jayathilake (2013) menyatakan bahwa perempuan lebih berperilaku menghindar risiko dibandingkan dengan lakilaki, maka dikembangkan rumuskan hipotesis sebagai berikut :

$\mathrm{H} 2$ : Auditor perempuan memiliki perilaku risiko yang lebih tinggi dibandingkan dengan auditor laki-laki dalam konteks audit atas laporan keuangan.

\section{Pengaruh Pendidikan Terhadap Perilaku Risiko Auditor}

Faktor terpenting selanjutnya yang dapat mempengaruhi perilaku risiko auditor adalah pendidikan. Tingkat pendidikan yang lebih tinggi secara umum berpengaruh secara positif terhadap pengambil risiko, semakin berpendidikan maka akan lebih menyukai risiko dengan imbal hasil yang sesuai. Penelitian yang dilakukan oleh Riley \& Chow (1992) menemukan bahwa semakin tinggi pendidikan seorang individu akan semakin menurunkan perilaku menghindar risikonya. Chang et al. (2004) pada penelitiannya yang menguji faktor umur, pendidikan, ras, status pernikahan, pekerjaan, dan kekayaan terhadap toleransi risiko menyimpulkan bahwa pada secara umum tingkat pendidikan tidak selalu menjadi faktor yang mempengaruhi keputusan investasi, tetapi pada umumnya, investor dengan tingkat pendidikan yang lebih tinggi akan berinvestasi pada investasi yang berisiko lebih tinggi. Hal ini bertentangan dengan penelitian Lin (2009) yang menguji pengaruh perbedaan latarbelakang risiko terhadap perilaku menghindar risiko dengan menggunakan data Survey of Family Income and Expenditure (SFIE) di Taiwan menemukan bahwa individu yang berpendidikan tinggi akan semakin berperilaku untuk menghindari risiko, semakin tinggi pendidikan yang diterima maka akan menimbulkan perilaku risk averse. Ketidakkonsistenan ini kemudian diuji kembali oleh Amaefula et al. (2012), pada penelitiannya mengenai perilaku risiko dan asuransi dengan pendekatan causal analysis, hasil penelitian tersebut menyatakan bahwa semakin tinggi tingkat pendidikan maka akan mempunyai pengaruh positif terhadap perilaku menghindar risiko. Penelitian selanjutnya yang dilakukan oleh Duasa \& Yusof (2013) menyatakan bahwa semakin banyak pendidikan formal yang dijalani oleh seseorang, maka akan menurunkan perilaku menghindar risikonya. Sehingga atas pertimbangan tersebut diatas, maka dapat dirumuskan hipotesis sebagai berikut :

H3 : Semakin tinggi pendidikan maka perilaku risiko auditor dalam konteks audit atas laporan keuangan akan semakin menurun.

\section{METODE PENELITIAN}

Penelitian ini merupakan penelitian eksplanatori dengan menggunakan kuesioner dan analisis data kuantitatif. Penelitian ini menggunakan kuesioner yang diantar langsung kepada auditor yang bekerja pada Kantor Akuntan Publik (KAP) di Indonesia dengan pemilihan sampel wilayah Surabaya, Bandung, dan Jakarta.

Alasan pemilihan sampel ini dikarenakan konsentrasi terbesar persebaran Akuntan Publik (AP) di Indonesia menurut profil AP dan KAP yang dikeluarkan oleh PPAJP tahun 2012 terletak pada pulau Jawa dengan 87 persen dari 1015 AP yang ada di Indonesia. Dimana dari 87 persen tersebut 68 persennya berada pada wilayah Jakarta dan sekitarnya, 6 persen pada wilayah Bandung dan sekitarnya, dan 12 persen pada wilayah Surabaya dan sekitarnya. Kondisi ini didukung dengan iklim yang lebih kondusif bagi pertumbuhan perekonomian di pulau Jawa dibandingkan dengan pulau yang lainnya. Kuesioner dalam penelitian ini menggunakan kuesioner Ionescu \& Turlea (2011) yang sedikit dimodifikasi dengan tujuan menambah informasi yang diperoleh dalam penelitian.

Populasi yang digunakan dalam penelitian ini adalah auditor yang bekerja pada KAP di Surabaya, Bandung, dan Jakarta. Metode pengambilan sample menggunakan metode simple random sampling dengan menggunakan fungsi $=$ RANDBETWEEN () pada microsoft excel 
2007, dimana setiap elemen populasi memiliki peluang yang diketahui dan sama untuk terpilih. Desain simple random sampling memiliki bias paling sedikit dan memberikan generalisasi paling luas (Sekaran, 2003 : 128). Besaran sampel populasi ditentukan dengan menggunakan rumus Slovin (Consuelo et al. 2007) sebagai berikut :

$$
\begin{gathered}
n=\frac{N}{1+N e^{2}} \\
\mathrm{n}=\frac{1016 x^{2}}{1+1016(0.1)^{2}}
\end{gathered}
$$

Berdasarkan perhitungan di atas, maka jumlah sampel yang digunakan dalam penelitian ini berjumlah 91 responden Auditor di KAP yang terlibat dalam perikatan audit atas laporan keuangan yang tersebar di wilayah Surabaya, Bandung, dan Jakarta.

\section{Definisi Operasional dan Pengukuran Variabel}

Definisi operasional variabel merupakan unsur penelitian yang memberitahukan mengenai tatacara mengukur suatu variabel penelitian maupun petunjuk pelaksanaan tentang tatacara mengukur sebuah variabel penelitian. Pertanyaan dalam kuesioner untuk masing-masing variabel dalam penelitian diukur dengan menggunakan skala Linkert. Selanjutnya definisi operasional dari setiap variabel sebagai berikut :

\section{Umur (X1)}

Umur adalah jumlah tahun yang telah dilewati seseorang sejak dilahirkan, umur diukur dari tanggal kelahiran hingga tanggal kini sebagai identifikasi level sosial atas (Santrock, 2011 : 12). Umur pada penelitian ini diukur dengan skala rasio (responden diminta langsung menuliskan umur pada kotak yang telah disediakan khusus).

\section{Gender (X2)}

Gender adalah dimensi sosiokultural dan psikologis dari laki-laki dan perempuan (Santrock, 2004 : 195). Gender pada penelitian ini diukur dengan variabel dummy, dimana 0 untuk responden laki-laki dan 1 untuk responden perempuan.

\section{Pendidikan (X3)}

Pendidikan adalah proses memperoleh pengetahuan pada institusi yang pasti sekolah tinggi, institut dan universitas (Jhonnie, 1993). Pendidikan diukur dengan menggunakan skala ordinal, yang kodifikasi menjadi lima, yaitu : Sarjana (S1) bernilai 1, Profesi Akuntansi (Ak) bernilai 2, Magister (S2) bernilai 3, dan Doktor (S3) bernilai 4.

\section{Perilaku Risiko Auditor (Y)}

Perilaku risiko auditor adalah keputusan risiko terkait yang muncul dari keputusan yang diambil orang-orang yang melaksanakan audit, biasanya rekan perikatan atau anggota team perikatan, keputusan berisiko yang dimaksud termasuk ketidakpastian yang lebih atas keluaran (outcomes) yang dihasilkan, penentuan tujuan yang sulit untuk dicapai, termasuk konsekuensi ekstrim yang harus diterima sebagai dampak dari keputusan, perilaku risiko auditor ini diukur dengan menggunakan kuesioner Ionescu \& Turlea (2011). Adapun indikator tersebut dibagi menjadi tiga, yaitu : IR (penilaian risiko teridentifikasi), AR (penilaian risiko secara keseluruhan), dan RA (kadar penghindaran terhadap risiko).

\section{HASIL PENELITIAN DAN PEMBAHASAN}

Tingkat Pengembalian Kuesioner Penelitian

Data penelitian dikumpulkan dengan cara menyebarkan 300 kuesioner pada auditor yang terlibat dalam audit atas laporan keuangan, sebanyak total 250 eksemplar disebarkan pada bulan Nopember dengan cara diantarkan langsung ke KAP sampling terpilih, dan 50 disebarkan saat pendidikan profesional lanjutan yang diadakan di STIESIA-Surabaya bekerja sama dengan IAPI.

Dari total 300 kuesioner yang disebarkan tersebut, terdapat beberapa kuesioner yang tidak kembali dan cacat dalam pengisiannya sehingga tidak memenuhi kualifikasi yang disyaratkan dalam penelitian ini. Rincian pengembalian, cacat pengisian, dan kuesioner tidak kembali sebagai berikut :

Tabel 1

Tingkat Pengembalian Kuesioner

\begin{tabular}{|c|c|}
\hline \multicolumn{1}{|c|}{ Keterangan } & Jumlah \\
\hline Jumlah Kuesioner & 300 \\
\hline $\begin{array}{l}\text { Kuesioner yang } \\
\text { diantar langsung }\end{array}$ & 250 \\
\hline Kuesioner yang & 50 \\
\hline
\end{tabular}




\begin{tabular}{|l|c|}
\hline \multicolumn{2}{|l|}{ disebar saat PPL } \\
\hline $\begin{array}{l}\text { Kuesioner yang } \\
\text { tidak kembali }\end{array}$ & 189 \\
\hline $\begin{array}{l}\text { Kuesioner yang } \\
\text { kembali }\end{array}$ & 111 \\
\hline $\begin{array}{l}\text { Kuesioner cacat/ } \\
\text { tidak diisi }\end{array}$ & 20 \\
\hline $\begin{array}{l}\text { Persentase tidak } \\
\text { kuesioner } \\
\text { kembali/ cacat/ } \\
\text { tidak diisi }\end{array}$ & $70 \%$ \\
\hline $\begin{array}{l}\text { Persentase } \\
\text { kuesioner yang } \\
\text { kembali }\end{array}$ & $30 \%$ \\
\hline
\end{tabular}

Sumber : Data primer yang diolah

\section{Statistik Frekuensi Penelitian \\ Umur}

Sebagian besar responden berumur 21-30 tahun dengan jumlah 59 orang (64.8\%), responden berumur 31-40 tahun berjumlah 13 orang $(14.3 \%)$, responden berumur 41-50 tahun berjumlah 8 orang $(8.8 \%)$, responden berumur 51-60 tahun berjumlah 4 orang (4.4\%), responden berumur 61-70 tahun berjumlah 5 orang (5.5\%), responden berumur $>70$ tahun berjumlah 2 orang $(2.2 \%)$.

\section{Gender}

Persebaran gender auditor yang menjadi responden, sebanyak 47 orang bergender lakilaki $(51.6 \%)$ sedangkan sisanya sebanyak 44 orang bergender perempuan (48.4\%).

\section{Pendidikan}

Sebanyak 48 orang berpendidikan sarjana (52.7\%), 20 orang berpendidikan profesi (22\%), 22 orang berpendidikan magister (24.2\%), dan 1 orang berpendidikan doktor $(1 \%)$.

\section{Teknik Analisis Data \\ Uji Kualitas Data \\ Uji Validitas}

Berikut disajikan hasil uji validitas variabel dependen yaitu perilaku risiko auditor yang dapat dilihat pada tabel 2 :
Tabel 2

Hasil Uji Validitas

\begin{tabular}{|c|c|c|}
\hline Variabel & $\begin{array}{c}\text { R hitung } \\
\text { (Pearson } \\
\text { Correlation) }\end{array}$ & Keterangan \\
\hline Y (Perilaku Risiko Auditor) \\
\hline IR & 0.825 & Valid \\
\hline AR & 0.826 & Valid \\
\hline RA & 0.603 & Valid \\
\hline
\end{tabular}

Sumber : Pengolahan Data SPSS 22

Berdasarkan tabel di atas dapat diketahui bahwa jika nilai $r$ hitung lebih besar dari $r$ tabel, yaitu $r$ tabel sebesar 0.30 maka data dari kuesioner dapat dinyatakan valid sehingga bisa dilanjutkan untuk pengolahan reliabilitas, karena tujuan dari uji validitas adalah untuk mengetahui apakah data hasil dari kuesioner telah sesuai untuk mengukur variabel penelitian.

\section{Uji Reliabilitas}

Realibilitas suatu variabel yang dibentuk dari daftar pertanyaan dikatakan baik jika memiliki nilai Cronbach's Alpha > dari 0.60. Berdasarkan hasil analisis data, cronbach's Alpha pada penelitian ini sebesar 0.612 dengan kata lain data yang diperoleh telah memenuhi kriteria reliabel. Untuk lebih jelasnya hal ini dapat di lihat pada lampiran 3 .

\section{Uji Asumsi Klasik}

Uji asumsi klasik dilakukan dalam penelitian kuantitatif sebelum dilakukannya proses pengujian hipotesis dengan menggunakan regresi linier berganda guna mengetahui ada tidaknya penyimpangan yang terjadi dalam model penelitian.

\section{Uji Normalitas}

Penyebaran titik disekitar garis diagonal merupakan indikasi pola distribusi normal, dengan kata lain model telah memenuhi kriteria asumsi normal. Hal ini juga berlaku sebaliknya.

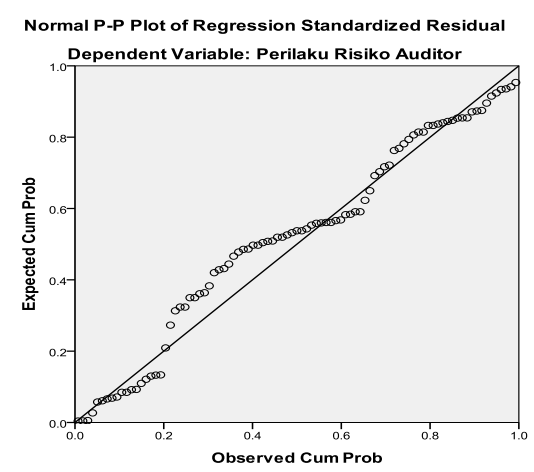




\section{Gambar 1 \\ Uji Normalitas}

Sumber : Pengolahan Data SPSS 22

Berdasarkan pada grafik normal plot diatas dapat disimpulkan bahwa titik persebaran berada disekitar dan searah dengan garis diagonal. Maka model regresi yang ada dapat digunakan untuk memprediksi perilaku risiko auditor.

\section{Multikolinearitas}

Untuk mendeteksi terjadinya multikolinieritas dapat dilihat dari Value Inflation Factor (VIF). Apabila nilai VIF > 10 maka terjadi multikolinearritas. Dan sebaliknya apabila VIF < 10 maka tidak terjadi multikolinearitas. Dalam penelitian ini diperoleh VIF seperti pada tabel 3 sebagai berikut :

Tabel 3

Uji Multikolinearitas Value Inflation Factor (VIF)

\begin{tabular}{|c|c|l|}
\hline Varibel & $\begin{array}{c}\text { Nilai } \\
\text { VIF }\end{array}$ & \multicolumn{1}{|c|}{ Keterangan } \\
\hline Umur & 1,743 & $\begin{array}{l}\text { Tidak ada } \\
\text { indikasi } \\
\text { kolinearitas } \\
\text { antar variabel } \\
\text { independen }\end{array}$ \\
\hline Gender & 1,132 & $\begin{array}{l}\text { Tidak ada } \\
\text { indikasi } \\
\text { kolinearitas } \\
\text { antar variabel } \\
\text { independen }\end{array}$ \\
\hline Pendidikan & 1,705 & $\begin{array}{l}\text { Tidak ada } \\
\text { indikasi } \\
\text { kolinearitas } \\
\text { antar variabel } \\
\text { independen }\end{array}$ \\
\hline
\end{tabular}

Sumber Data : Data sekunder yang diolah

Keterangan:-Jumlah data (observasi) $=91$

- Nilai $t_{\text {tabel }}: \alpha=5 \%=1,980$

-Variabel Terikat PERILAKU RISIKO AUDITOR

Berdasarkan tabel tersebut dapat disimpulkan bahwa variabel (Umur, Gender, dan Pendidikan) tidak terjadi multikolineritas yang ditunjukkan dengan nilai VIF lebih kecil dari 10.

\section{Heterokedastisitas}

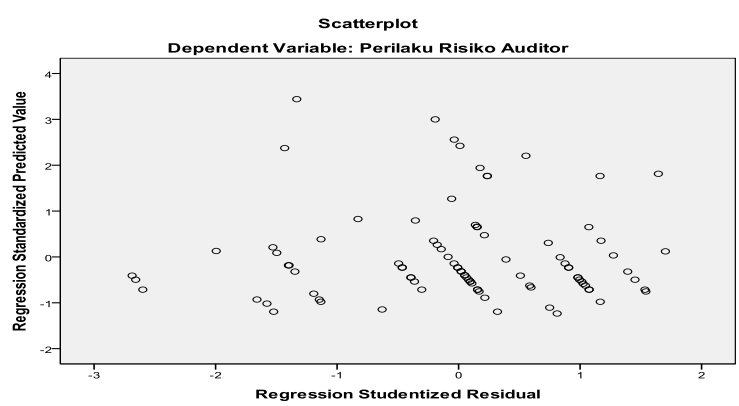

Gambar 2

Uji Heteroskedastisitas

Sumber : Pengolahan Data SPSS 22

Dari gambar scatterplot di atas dapat dilihat bahwa titik-titik menyebar secara acak serta tersebar baik di atas maupun di bawah angka 0 pada sumbu y. Hal ini menunjukkan bahwa tidak terjadi heterokedastisitas pada model regresi, sehingga model layak dipakai untuk menganalisa data.

\section{Analisis Regresi Linier Berganda}

Pengujian analisis regresi linier berganda dilakukan untuk mengetahui adanya pengaruh antara umur (X1), gender (X2), dan pendidikan (X3) terhadap perilaku risiko auditor (Y). Adapun hasil pengujian analisis regresi linier berganda dapat diamati pada tabel 4 berikut :

Tabel 4

Hasil Analisis Regresi

\begin{tabular}{|l|c|c|c|c|}
\hline Variabel & $\begin{array}{c}\text { Unstan } \\
\text { dardize } \\
\mathbf{d} \\
\text { Coeffici } \\
\text { ents (B) }\end{array}$ & $\begin{array}{c}\mathbf{t} \\
\text { hitun } \\
\mathbf{g}\end{array}$ & Sig. & $\begin{array}{c}\text { Keteran } \\
\text { gan }\end{array}$ \\
\hline $\begin{array}{c}\text { (Constant } \\
\text { ) }\end{array}$ & 7.257 & & & $\begin{array}{c}\text { Signifika } \\
\mathrm{n}\end{array}$ \\
\hline Umur & 0.065 & 2.851 & 0,0 & $\begin{array}{c}\text { Signifika } \\
\mathrm{n}\end{array}$ \\
\hline Gender & 0.356 & 0.718 & 0.4 & $\begin{array}{c}\text { Tidak } \\
\text { signifika }\end{array}$ \\
\hline
\end{tabular}




\begin{tabular}{|l|l|c|c|c|}
\hline & & & 75 & $\mathrm{n}$ \\
\hline $\mathrm{n}$ & & 0.638 & 25 & $\begin{array}{c}\text { signifika } \\
\mathrm{n}\end{array}$ \\
\hline $\mathrm{R}$ & & $=0.320$ \\
R Square & $=0.103$ \\
Adjusted R Square & $=0.072$ \\
F hitung & $=3.320$ \\
F tabel & $=2.68$ \\
Sign. F & $=0.024$ \\
$\alpha$ & $=0.05$ \\
\hline
\end{tabular}

Sumber data : Data primer yang diolah

Keterangan : -Jumlah data (observasi) $=91$

$$
\text { - Nilai } \mathrm{T}_{\text {tabel }}: \alpha=5 \%=1,980
$$

Risiko Auditor

Dependent Variabel Perilaku

Variabel dependen pada model regresi linier berganda ini adalah Perilaku Risiko Auditor sedangkan variabel independen adalah Umur, Gender, dan Pendidikan. Model regresi berdasarkan hasil analisis di atas adalah :

$$
\begin{gathered}
\mathrm{Y}_{1}=7,257+0,065 \mathrm{AGE}+0,356 \mathrm{GEN}-0,225 \\
\mathrm{ED}+\mathrm{e}
\end{gathered}
$$

Tampak pada persamaan tersebut menunjukkan angka yang signifikan pada variabel Umur adapun interpretasi dari persamaan tersebut dapat dijelaskan pada pemaparan berikut :

1. $b o=7,257$

Nilai konstan ini menunjukkan bahwa apabila tidak ada yang tercermin pada (Umur, Gender, dan Pendidikan =0) maka besarnya Perilaku Risiko Auditor akan meningkat sebesar 7,257 kali. Artinya, besaran Perilaku Risiko Auditor akan meningkat 7,257 kali sebelum atau tanpa adanya variabel dependen yang tercermin pada (Umur, Gender dan Pendidikan $=0$ ).

2. $b_{1}=0,065$

Nilai parameter atau koefisien regresi $b_{1}$ ini menunjukkan bahwa setiap variabel
Umur meningkat 1 kali, maka besarnya Perilaku Risiko Auditor akan meningkat sebesar 0,065 kali dengan asumsi variabel bebas yang lain tetap (Gender dan Pendidikan $=0$ ) atau Cateris Paribus.

3. $b_{2}=0,356$

Nilai parameter atau koefisien regresi $b_{2}$ ini menunjukkan bahwa setiap variabel Gender meningkat 1 kali, maka besarnya Perilaku Risiko Auditor akan meningkat sebesar 0,356 kali atau dengan kata lain setiap peningkatan Perilaku Risiko Auditor dibutuhkan variabel Gender sebesar 0,356 dengan asumsi variabel bebas yang lain tetap (Umur dan Pendidikan $=0$ ) atau Cateris Paribus.

4. $b_{3}=0.225$

Nilai parameter atau koefisien regresi $b_{3}$ ini menunjukkan bahwa setiap variabel Pendidikan meningkat 1 kali, maka besarnya Perilaku Risiko Auditor akan meningkat sebesar 0,225 kali atau dengan kata lain setiap peningkatan Perilaku Risiko Auditor dibutuhkan variabel Pendidikan sebesar 0,225, dengan asumsi variabel bebas yang lain tetap (Umur dan Gender $=0$ ) atau Cateris Paribus.

\section{Hasil Pengujian Hipotesis}

Terdapat tiga hipotesis yang diuji dengan menggunakan multiple regresion. Tujuannya adalah untuk mengetahui apakah Umur, Gender, dan Pendidikan berpengaruh terhadap Perilaku Risiko Auditor. Berikut ini hasil uji perhitungan $t$ dan $R^{2}$ pada tabel 5

Tabel 5

Perhitungan Pengujian Hipotesis

\begin{tabular}{|l|l|l|l|}
\hline No & \multicolumn{1}{|c|}{ Hipotesis } & \multicolumn{1}{|c|}{ Nilai } & \multicolumn{1}{|c|}{ Keterangan } \\
\hline 1 & $\begin{array}{l}\text { Umur } \\
\text { berpengaruh } \\
\text { positif } \\
\text { terhadap } \\
\text { Perilaku } \\
\text { Risiko } \\
\text { Auditor }\end{array}$ & $\begin{array}{l}\text { t,851 } \\
\text { Sig } \\
=\end{array}$ & $\begin{array}{l}\text { H1 tidak } \\
\text { ditolak }\end{array}$ \\
& $\begin{array}{l}\mathrm{t}_{\text {tabel }}=005 \\
1,980\end{array}$ \\
\hline 2 & $\begin{array}{l}\text { Gender } \\
\text { berpengaruh } \\
\text { positif } \\
\text { terhadap } \\
\text { Perilaku }\end{array}$ & $\begin{array}{l}\mathrm{t}= \\
0,718 \\
\text { Sig }=\end{array}$ \\
\hline
\end{tabular}




\begin{tabular}{|c|c|c|c|}
\hline & $\begin{array}{l}\text { Risiko } \\
\text { Auditor }\end{array}$ & $\begin{array}{l}0,475 \\
\mathrm{t}_{\text {tabel }}= \\
1,980\end{array}$ & \\
\hline 3 & $\begin{array}{l}\text { Pendidikan } \\
\text { berpengaruh } \\
\text { negatif } \\
\text { terhadap } \\
\text { Perilaku } \\
\text { Risiko } \\
\text { Auditor }\end{array}$ & $\begin{array}{l}\mathrm{t}= \\
-0,638 \\
\text { Sig } \mathrm{t} \\
= \\
0,525 \\
\mathrm{t}_{\text {tabel }}= \\
1,980\end{array}$ & H3 ditolak \\
\hline
\end{tabular}

Sumber data : Data sekunder yang diolah

Pengujian $\mathrm{H}_{1}$ sampai dengan $\mathrm{H}_{3}$ dilakukan dengan uji t. Untuk $\mathrm{H}_{1}$ nilai $\mathrm{t}_{\text {statistik }}$ sebesar 2,851 . Nilai ini lebih besar dari t tabel $(2,851>$ 1,980). Dengan demikian pengujian menunjukkan H1 tidak ditolak. Hasil ini memperlihatkan bahwa umur berpengaruh secara positif dan signifikan terhadap Perilaku Risiko Auditor.

Untuk $\mathrm{H}_{2}$ nilai $\mathrm{t}_{\text {statistik }}$ sebesar 0,718 Nilai ini lebih kecil dari $\mathrm{t}$ tabel $(0,718<1,980)$. Dengan demikian pengujian menunjukkan $\mathrm{H} 2$ ditolak. Hasil ini memperlihatkan bahwa auditor perempuan tidak lebih berperilaku menghindar risiko dibandingkan dengan auditor laki-laki.

Untuk $\mathrm{H}_{3}$ nilai $\mathrm{t}_{\text {statistik }}$ sebesar $-0,638$. Nilai ini lebih kecil dari $\mathrm{t}$ tabel $(-0,638<1,980)$. Dengan demikian pengujian menunjukkan H3 ditolak. Hasil ini memperlihatkan bahwa auditor yang pendidikan lebih tinggi tidak lebih berperilaku menghindar risiko dibandingkan dengan auditor dengan pendidikan dibawahnya.

Kesimpulan yang dapat diambil berdasarkan hasil pengujian hipotesis di atas adalah variabel umur, gender, dan pendidikan tidak berpengaruh secara serentak terhadap perilaku risiko auditor, akan tetapi secara parsial hanya variabel umur yang berpengaruh secara signifikan terhadap perilaku risiko auditor, sedangkan sisanya gender dan pendidikan tidak berpengaruh secara signifikan terhadap perilaku risiko auditor. Setelah dilakukan pengujian model, maka langkah selanjutnya adalah dilakukan perhitungan korelasi untuk mengukur ketepatan garis regresi dalam menjelaskan variasi nilai variabel independen.

Hasil analisis korelasi yang diperoleh dari output regresi (lampiran) mengkorelasi pengaruh variabel demografis yang diwakili oleh Umur, Gender, dan Pendidikan terhadap Perilaku Risiko Auditor diperoleh nilai $\mathrm{R}^{2}=$ 0.103 . Angka ini menunjukkan bahwa variasi Perilaku Risiko Auditor yang dapat dijelaskan oleh persamaan regresi yang diperoleh sebesar $10.3 \%$ sedangkan sisanya, yaitu $89.7 \%$, dipengaruhi oleh variabel lain di luar persamaan model. $\mathrm{R}$ sebesar 0.320 artinya korelasi antara variable Umur, Gender, dan Pendidikan terhadap Perilaku Risiko Auditor adalah cukup kuat.

\section{Pengaruh Umur terhadap Perilaku Risiko Auditor dalam konteks audit atas laporan keuangan.}

Pola pikir seorang auditor tentunya akan semakin berkembang searah dengan peningkatan rentang kehidupan yang dilalui. Selama rentang kehidupan tersebut tentunya akan terjadi proses pematangan pengalaman sehingga dapat menghasilkan perbedaan persepsi mengenai risiko. Dalam auditing pematangan umur auditor tidak akan terlepas dari persepsinya terhadap risiko, khususnya risiko audit. Hal ini lebih jauh berguna dalam hal penilaian dan respon terhadap risiko, dimana terdapat pilihan bagi auditor untuk cenderung berperilaku menyukai atau menghindari risiko audit yang ada.

Dari penelitian yang telah dilakukan, diperoleh hasil bahwa umur mempunyai pengaruh signifikan terhadap perilaku risiko auditor. Pengaruh yang ditimbulkan adalah positif, karena dengan adanya variabel umur dapat meningkatkan perilaku risiko auditor. Hal ini disebabkan auditor yang lebih berumur cenderung untuk bersikap lebih skeptis dan konservatif terhadap risiko yang dihadapinya.

Hasil penelitian ini bertentangan dengan penelitian yang dilakukan oleh Wang \& Hanna (1997), Lin (2009), dan Amaefula et al. (2012) yang menyatakan bahwa semakin bertambahnya umur, perilaku menghindar risiko akan semakin menurun, dengan kata lain perilaku menyukai risiko akan semakin bertambah. Penelitian ini searah dengan penelitian yang dilakukan oleh (Riley \& Chow, 1992; Bellante \& Green, 2004; Chang et al., 2004; Gardner \& Steinberg, 2005; Grable et al., 2009; Chauffman et al., 2010; Ionescu \& Turlea, 2011; Yao et al., 2011; Rolison et al., 2012; Duasa \& Yusof, 2013) yang berkesimpulan bahwa semakin berumur seseorang, maka akan semakin menghindari terhadap risiko yang dihadapinya. Dalam 
konteks penelitian ini, semakin bertambah umur auditor yang terlibat dalam audit atas laporan keuangan entitas, maka perilaku menghindar risiko audit akan semakin meningkat. Hal ini tentunya akan berarti bahwa dalam menentukan faktor-faktor yang terlibat dengan risiko audit, auditor akan cenderung lebih skeptis dan konservatif, baik dalam rangka menilai dan merespon risiko hingga pada proses penerimaan klien dan pengumpulan bukti audit.

\section{Pengaruh Gender terhadap Perilaku Risiko Auditor dalam konteks audit atas laporan keuangan.}

Gender merupakan hal yang membedakan antara laki-laki dan perempuan, perbedaan yang timbul dapat membuat intensi perilaku dan pola berpikir yang berbeda. Dalam hal perilaku risiko, tidak sedikit penelitian yang menyatakan bahwa perempuan akan selalu lebih bersikap untuk menghindari risiko dibandingkan dengan laki-laki (Barber \& Odean, 2001; Faff et al., 2008; dan Jayathilake, 2013).

Penelitian ini menunjukkan hasil yang berbeda dengan penelitian-penelitian yang dilakukan oleh Barber \& Odean (2001), Faff $e t$ al. (2008), dan Jayathilake (2013) yang menyatakan bahwa perempuan lebih berperilaku menghindari risiko dibandingkan dengan laki-laki. Gender tidak mempunyai pengaruh signifikan terhadap perilaku risiko auditor. Hasil penelitian ini menunjukkan hasil yang sama dengan penelitian yang dilakukan oleh Wendy (2010) yang menyatakan tidak ada perbedaan perilaku risiko antara laki-laki dan perempuan. Hal ini dikarenakan faktor perilaku risiko tidak hanya dipengaruhi oleh faktor gender saja, tetapi masih banyak faktor lain yang dapat mempengaruhi, antara lain pengalaman dan karakteristik lingkungan disekitarnya. Dalam konteks penelitian ini, auditor perempuan tidak menunjukkan perilaku risiko yang berbeda dengan auditor laki-laki dalam hal menilai dan merespon risiko audit yang dihadapinya, berarti bahwa tidak ada perbedaan penerimaan terhadap risiko audit. Gender bukan merupakan faktor satu-satunya yang dapat mempengaruhi perilaku risiko auditor, tetapi masih ada banyak faktor lainnya yang dapat dipertimbangkan, seperti kompetensi, pengalaman, time pressure, fee audit, dsb.
Pengaruh Pendidikan terhadap Perilaku Risiko Auditor dalam konteks audit atas laporan keuangan.

Keberadaan pendidikan melekat selama umur manusia khususnya auditor dalam mempertahankan profesionalitas dan pengatahuan yang dimilikinya. Menurut Johnnie (1993) pendidikan adalah proses memperoleh pengetahuan dan dapat menggunakan pengetahuan tersebut dalam memahami aktivitas dan lingkungan disekitar kita. Pendidikan merupakan satu dari beberapa item yang persyaratan kompetensi dalam SPM no 1 guna memenuhi kualifikasi dasar sebagai auditor, hal tersebut juga yang menjadi pertimbangan utama dalam penelitian ini mengaitkan pengaruh pendidikan terhadap perilaku risiko dalam kaitan risiko audit atas laporan keuangan entitas. Pendidikan seharusnya secara langsung maupun tidak dapat mempengaruhi pola pikir dan kecenderungan auditor dalam menghadapi risiko audit. Namun kenyataannya hasil penelitian ini menunjukkan bahwa pendidikan tidak memiliki pengaruh signifikan terhadap perilaku risiko auditor. Kendati demikian terdapat pengaruh negatif antara pendidikan dan perilaku auditor.

Hasil penelitian ini menunjukkan hasil yang berbeda dengan penelitian yang dilakukan oleh Lin (2009), dan Amaefula et al. (2012) yang menyatakan bahwa semakin berpendidikan, maka perilaku menghindar risiko akan semakin meningkat. Hasil penelitian ini menunjukkan hasil yang sama dengan penelitian yang dilakukan oleh Grable et al. (2009) dan Jayathilake (2013) yang menyatakan tidak ada bukti signifikan yang menunjukkan pengaruh pendidikan dengan perilaku risiko yang ada. Hal ini disebabkan oleh perolehan pengetahuan mengenai risiko yang ada khususnya risiko audit tidak terbatas hanya terdapat pada formal pendidikan yang dilalui oleh auditor. Banyak faktor lain yang dapat menjadikan auditor paham akan risiko yang dihadapinya, antara lain dari pengalaman, pelatihan, dan kursus.

\section{SIMPULAN DAN SARAN}

\section{Simpulan}

Penelitian ini bertujuan untuk menguji pengaruh antara umur, gender, dan pendidikan terhadap perilaku risiko auditor dalam konteks audit atas laporan keuangan. Dari hasil analisis yang telah dilakukan maka simpulan penelitian antara lain, sebagai berikut : 
1. Umur berpengaruh positif terhadap perilaku risiko auditor dalam konteks audit atas laporan keuangan.

2. Auditor perempuan tidak terbukti lebih berperilaku menghindar risiko dibandingkan dengan laki-laki.

3. Pendidikan formal yang lebih tinggi tidak terbukti secara signifikan berpengaruh terhadap perilaku risiko auditor.

4. Adanya kombinasi umur, gender, dan pendidikan yang beragam dalam team berguna dalam efisiensi dengan tetap menjaga efektifitas audit yang dilakukan melalui adanya kombinasi perilaku risiko yang melekat pada masing-masing kriteria tersebut.

\section{Keterbatasan}

1. Pada penelitian ini perilaku risiko auditor diukur dengan IR (penilaian risiko teridentifikasi), AR (penilaian risiko secara keseluruhan), dan RA (kadar penghindaran terhadap risiko). Ketiga indikator tersebut belum dapat sepenuhnya menjadi tolak ukur perilaku risiko auditor karena penelitian ini hanya membahas mengenai perilaku risiko auditor dalam konteks audit atas laporan keuangan. Sedangkan dalam profesi audit, jasa yang ditawarkan tidak terbatas pada audit atas laporan keuangan saja.

2. Pada penelitian ini klasifikasi auditor yang lebih berumur dan lebih berpendidikan masih belum dapat disebutkan dengan jelas batasannya, sehingga pada penafsirannya masih cenderung bias.

\section{Saran}

1. Penelitian kedepan diharapkan untuk melakukan penelitian perilaku risiko auditor secara menyeluruh, tidak terbatas hanya audit atas laporan keuangan saja, tetapi menilai perilaku risiko auditor dengan cakupan yang lebih kompleks dan utuh.

2. Penelitian selanjutnya diharapkan untuk menentukan kriteria yang lebih jelas mengenai kriteria lebih berumur dan lebih berpendidikan, begitu juga sebaliknya.

\section{Implikasi \\ Bagi Auditor}

Umur perlu diperhatikan, karena semakin berumur auditor akan semakin skeptis dan konservatif terhadap bukti, sehingga dapat berdampak pada tingginya waktu dan biaya yang dibutuhkan, sehingga perlu untuk mengatur kombinasi umur auditor yang melakukan audit atas laporan keuangan untuk mencapai tujuan audit berbasis risiko yang disyaratkan oleh Standar Profesional Akuntan Publik (SPAP).

Tidak adanya perbedaan perilaku risiko antara auditor laki-laki dan perempuan dapat menjadi titik temu bagi auditor dalam melakukan pelatihan yang memadai sesuai yang disyaratkan oleh Standar Pengendalian Mutu (SPM) sehingga persepsi mengenai risiko ada dapat diterapkan dilapangan dengan memadai dan sesuai kriteria standar, dalam hal penugasan audit, tidak perlu juga untuk membedakan antara auditor perempuan dan auditor laki-laki dalam industri tertentu, tidak adanya perbedaan persepsi mengenai risiko juga merupakan peluang bagi auditor untuk melakukan seleksi penerimaan staf dengan cara yang lebih efisien yaitu cukup dengan satu cara/ metode, tanpa membedakan perempuan dan laki-laki.

Fakta yang ada di Indonesia justru berkata sebaliknya bahwa semakin berpendidikan auditor, maka auditor tersebut akan cenderung menghindari risiko, hal ini menunjukkan bahwa masih belum ada titik temu yang memadai antara dunia pendidikan dan praktisi. Dengan adanya SPAP yang baru dengan pendekatan audit berbasis risiko diharapkan auditor yang lebih berpendidikan akan dapat menilai risiko secara moderat, tidak terlalu menghindari risiko, sehingga audit atas laporan keuangan dapat dilakukan dengan lebih efisien dari segi waktu dan biaya

\section{Bagi Akademisi}

Umur merupakan tantangan tersendiri untuk mencapai kompetensi yang disyaratkan oleh SPAP sebagai kualifikasi seorang auditor, kondisi ini diperparah dengan rendahnya minat akademisi untuk terjun pada Kantor Akuntan Publik (KAP) sebagai auditor keuangan yang disebabkan oleh minimnya sosialisasi tenaga pendidik terhadap mahasiswa tentang prospek dan peluang karir sebagai auditor, sehingga profesi auditor dianggap sulit, tidak menyenangkan, dan berpenghasilan rendah menjadi sebaliknya, perlu upaya pendidik untuk mensosialisasikan bahwa profesi auditor menarik dan penuh dengan peluang karir yang jelas.

Adanya kesamaan peran gender terhadap perilaku risiko tentunya menjadi peluang tersendiri tenaga pendidik untuk memberikan pengajaran dengan metode yang sama. 
Fakta bahwa semakin berpendidikan auditor akan semakin menghindari risiko hal ini perlu disikapi dengan pemberian materi pada perkuliahan yang lebih mendekati dunia praktek agar cikal bakal auditor dapat memiliki persepsi yang moderat terhadap risiko, sehingga audit atas laporan keuangan dapat dilaksanakan dengan lebih efisien dari segi waktu dan biaya.

\section{DAFTAR PUSTAKA}

Amaefula, C., Okezie, C. A., \& Mejeha, R. (2012). Risk Attitude and Insurance : A Causal Analysis. American Journal of Economics, 2 (3), 26-32. doi: 10.5923/j.economics.20120203.01

Barber, B., \& Odean, T. (2001). Boys Will Be Boys : Gender, Overconvidence, and Common Stock Investment. Journal of Economic, 261-292.

Bellante, D., \& Green, A. C. (2004). Relative Risk Aversion the Elderly. Review of Financial Economics, 13, 269-281.

Chauffman, E., Shulman, E. P., Steinberg, L., Claus, E., Banich, M. T., Graham, S., \& Woolard, J. (2010). Age Differences in Affective Decision Making as Indexed by Performance on the Iowa Gambling Task. Developmental Psychology, 46 (1), 193-207. doi: 10.1037/a0016128

Chang, C.-C., Devaney, S. A., \& Chiremba, S. T. (2004). Determinants of Subjective and Objective Risk Tolerance. Journal of Personal Finance, 3 (3), 53-67.

Dror, I. E., Katona, M., \& Mungur, K. (1998). Age Differences in Decision Making : To Take Risk or Not? Gerontology, 44, 67-71.

Duasa, J., \& Yusof, S. A. (2013). Determinants of Risk Tolerance on Financial Asset Ownership : A Case of Malaysia. International Journal of Business and Society, 14 (1), 1-16.

Elder, R. J., Mark, B. S., \& Alvin, A. A. (2008). Auditing and Assurance Services An Integrated Approach (12 ed.). New Jersey: Pearson Education.

Faff, R., Mulino, D., \& Chai, D. (2008). On The Linkage Between Financial Risk Tolerance and Risk Aversion. The Journal of Financial Research, XXXI (1), 1-23.

Festinger, Leon. (1962). Cognitive Dissonance. Scientific American Offprints, Vol 200. No.4 pp 93102.

Gardner, M., \& Steinberg, L. (2005). Peer Influence in Risk Taking, Risk Preference, and Risky Decision Making in Adolescence and Adulthood : An Experimental Study. Developmental Psychology, 41 (4), 625-635. doi: 10.1037/0012-1649.41.4.625

Grable, J. E., McGill, S., \& Britt, S. (2009). Risk Tolerance Estimation Bias : The Age Effect. Journal of Business \& Economics Research, 7 (7).

$\mathrm{Http}: / / \mathrm{www} \cdot$ google.com/url? $\mathrm{sa}=\mathrm{t} \& \mathrm{rct}=\mathrm{j} \& \mathrm{q}=\& \mathrm{esrc}=\mathrm{s} \&$ source=web\& $\mathrm{cd}=3 \& \mathrm{cad}=\mathrm{rja} \& \mathrm{ved}=0 \mathrm{CEgQFjA}$ C\&url=http\%3A\%2F\%2Fwww.ppajp.depkeu.go.id\%2Fremository\%2Fdownloads\%2FProfil \%2520AP\%2520dan\%2520KAP.pdf\&ei=WoKFUpHrCo-

lkgWQsoG4AQ\&usg=AFQjCNFeXnBfcCdT15qVM06v23mp5lpp1Q\&sig2=b4jLmKitQtmnt gS6Y7XUJw\&bvm=bv.56643336,d.dGI. Diakses 9 Februari 2013.

Indonesia., I. A. P. (2013). Standar Profesional Akuntan Publik Tujuan Keseluruhan Auditor Independen dan Pelaksanaan Audit Berdasarkan Standar Audit. Jakarta: Salemba Empat.

Ionescu, I. O., \& Turlea, E. (2011). The Financial Auditor's Risk Behaviour-The Influence of Age on Risk Behaviour in A Financial Audit Context. Accounting and Management Information Systems, 10 (4), 444-458.

Jayathilake, P. M. B. (2013). Gender Effects on Risk Perception and Risk Behavior of Entrepreneurs at SMES in Sri Lanka. Asia Pasific Journal of Marketing \& Management Review, 2 (2).

Johnnie, P. (1993). Formal Education : A Paradigm of Human Resource Development. The International Journal of Educational Management, 7 (5), 4-8.

Riley, W. B., \& Chow, K. V. (1992). Asset Allocation and Individual Risk Aversion. Financial Analysts Journal, 48 (6), 32-37. 
Rolison, J. J., Hanoch, Y., \& Wood, S. (2012). Risky Decision Making in Younger and Older Adults :

The Role of Learning. Psychology and Aging, 27 (1), 129-140. doi: 10.10137/a0024689

Santrock, J. W. (2004). Educational Psychology (2 ed.). New York: McGraw-Hill Companies, Inc.

Santrock, J. W. (2011). Life Span Development (13 ed.). New York: McGraw-Hill Companies, Inc.

Sitkin, S. B., \& Pablo, A. L. (1992). Reconceptualizing The Determinants of Risk Behavior.

Academic of Management Review, 17 (1), 9-38.

Wang, H., \& Hanna, S. (1997). Does Risk Tolerance Decrease With Age? Financial Counseling and Planning, 8 (2).

Wendy. (2010). Apakah Investor Saham Menderita Myopic Loss Aversion? Eksperimen Laboratori. Jurnal Bisnis dan Ekonomi (JBE), 17 (2), 85-96.

Yao, R., Sharpe, D. L., \& Wang, F. (2011). Decomposing the Age Effect on Risk Tolerance. The Journal of Socio-Economics, 40, 879-887. doi: 10.1016/j.soec.2011.08.023

\section{LAMPIRAN KUESIONER PENELITIAN}

Anda akan diminta untuk menjawab beberapa pertanyaan, beberapa pertanyaan mensyaratkan anda untuk membuat keputusan dalam situasi yang dapat diduga, pertanyaan lainnya mensyaratkan anda untuk menyatakan pendapat anda.

Segala informasi yang anda sediakan akan digunakan hanya untuk tujuan penelitian saja dan akan dijamin kerahasiaannya. Anda tidak akan dapat diidentifikasi dari informasi yang telah anda sediakan.

Peneliti harap anda dapat menyelesaikan questioner dengan senang hati dan terima kasih atas waktu yang telah diberikan untuk menjawab pertanyaan dalam questioner ini

\section{Pertanyaan 1.}

Berapa umur anda?

- Jenis Kelamin

- Pendidikan Terakhir
: 1) Laki-laki
2) Perempuan
: 1) S1 (Sarjana)
3) S2 (Magister)
2) Profesi (PPA)
4) S3 (Doktor)

\section{Pertanyaan 2.}

Anda terpilih menjadi auditor PT ABC, sepanjang pengetahuan anda perusahaan tersebut merupakan developer menengah dengan shareholder yang juga menjadi manajemen perusahaan. Anda mengetahui bahwa perusahaan telah menginvestasikan sejumlah besar 
cadangan keuangannya pada pembangunan area perumahan yang dalam tahap penyelesaian. anda mengetahui jika perusahaan mengatur untuk menjual semua rumah yang ada pada area perumahan di tahun berjalan, maka sejumlah besar penjualan tersebut akan berhasil, tidak hanya secara keuangan tetapi juga secara market share. Tetapi jika perusahaan tidak menjual semua rumah yang ada pada area perumahan tersebut, perusahaan akan dihadapkan dengan permasalahan likuiditas yang serius serta permasalahan reputasi yang ada. Anda juga mengetahui bahwa ada $60 \%$ peluang perusahaan akan menjual semua rumah dan $40 \%$ peluang perusahaan tidak dapat menjual semua rumah.

Asumsikan bahwa hanya informasi ini yang diperoleh, mohon nyatakan pendapat anda atas pernyataan berikut ini :

\section{Risiko bawaan (inherent risk) pada PT ABC adalah rendah}

Jawaban :

(Dimohon untuk tick mark $(\sqrt{ })$ hanya pada satu kotak)

\begin{tabular}{|c|c|c|c|c|c|}
\hline $\begin{array}{l}\text { Amat Sangat } \\
\text { Setuju }\end{array}$ & Sangat Setuju & Setuju & Tidak Setuju & $\begin{array}{c}\text { Sangat Tida } \\
\text { Setuju }\end{array}$ & $\begin{array}{l}\text { Amat Sangat } \\
\text { Tidak Setuiu }\end{array}$ \\
\hline
\end{tabular}

\section{Pertanyaan 3.}

Pendekatan terkini mengenai audit atas laporan keuangan satu diantaranya berdasarkan risiko. Pendekatan audit berdasarkan risiko didasarkan pada tujuan perusahaan : kepastian tingkat keuntungan, mendapatkan kepastian market share, memperbaiki kepastian tingkat likuiditas, peningkatan merk dagang, dll. Dengan mempertimbangkan kasus pada PT ABC, yang disajikan pada pertanyaan sebelumnya (pertanyaan 2), mohon nyatakan pendapat anda atas pernyataan berikut ini :

\section{Risiko bisnis pada kasus PT ABC (risiko jika perusahaan gagal meraih tujuan strategisnya) adalah kecil}

Jawaban :

(Dimohon untuk tick mark $(\sqrt{ })$ hanya pada satu kotak) 

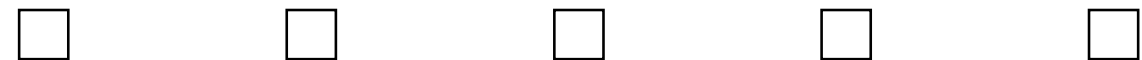

\section{Pertanyaan 4.}

Asumsikan bahwa anda larut dan hidup dalam gaya hidup yang nyaman, diluar yang anda miliki, anda diberi uang sebesar USD 1,000 dengan kondisi yang mengharuskan anda untuk memilih diantara dua pilihan :

Anda dapat mengambil risiko (berjudi) USD 1,000 - dengan 50\% peluang untuk menang, dalam hal ini anda menyimpan USD 1,000 (seluruhnya), dan dengan 50\% peluang untuk kalah, dalam hal ini anda kehilangan uang USD 1,000 (seluruhnya).

Atau

Anda dapat menyimpan USD 500 dari USD 1000 tanpa judi.

Mohon nyatakan pendapat anda atas pernyataan berikut ini :

Mengambil risiko (berjudi) USD 1,000 adalah pilihan yang lebih baik

Jawaban :

(Dimohon untuk tick mark $(\sqrt{ })$ hanya pada satu kotak)

\begin{tabular}{|c|c|c|c|c|c|}
\hline $\begin{array}{c}\text { Amat Sangat } \\
\text { Setuju }\end{array}$ & Sangat Setuju & Setuju & Tidak Setuju & $\begin{array}{c}\text { Sangat Tidak } \\
\text { Setuju }\end{array}$ & $\begin{array}{l}\text { Amat Sanga } \\
\text { Tidak Setuj }\end{array}$ \\
\hline
\end{tabular}

